\title{
Lead poisoning secondary to unprescribed ayurvedic medicine intake
}

\author{
Uday Yanamandra (D) ,' Venkatesan Somasundaram, ${ }^{2}$ Rajat Bahl, ${ }^{1}$ \\ Suman Kumar Pramanik'
}

'Department of Hematology, Army Hospital Research and Referral, Delhi, India ${ }^{2}$ Hematopathology, Army Hospital Research and Referral, Delhi, India

\section{Correspondence to Dr Uday Yanamandra; udayj2@gmail.com}

Accepted 8 October 2020

Check for updates

(c) BMJ Publishing Group Limited 2020. No commercial re-use. See rights and permissions. Published by BMJ.

To cite: Yanamandra $U$, Somasundaram $\mathrm{V}$, Bahl $R$, et al. BMJ Case Rep 2020;13:e238576. doi:10.1136/bcr-2020238576

\section{DESCRIPTION}

Lead, an ubiquitous toxicant emitted from environmental and industrial sources, causes multiple adverse effects following acute or chronic exposure. Sometimes the sources of heavy metal exposure are unanticipated. We report a case of acute lead poisoning presenting with adverse haematological manifestations following ingestion of ayurvedic medicine.

A 30-year-old wrestler presented with complaints of pain in the epigastrium, episodic vomiting, constipation and easy fatigability following consumption of unsupervised ayurvedic medicines (figure 1) for a duration of one month. On clinical examination the patient had pallor with mild hepatomegaly. He did not have features of lead encephalopathy, neuropsychiatric/cognitive effects, peripheral neuropathy or lead nephropathy. His evaluation revealed microcytic hypochromic anaemia (haemoglobin $96 \mathrm{~g} / \mathrm{L}$, total leukocyte count $6.92 \times 10^{9} / \mathrm{L}$ and platelets $214 \times 10^{9} / \mathrm{L}$ ), with reticulocyte count of $0.06 \%$ and no evidence of basophilic stippling or haemolysis on peripheral blood smear. Bone marrow (figure 2A) showed cellular marrow with increased iron stores (Perls' stain: grade 4), with no ring sideroblasts (figure $2 \mathrm{~B}, \mathrm{C}$ ) and dyspoietic megakaryocytes (figure 2D). Radiological evaluation revealed mild hepatomegaly. Due to history of prolonged ayurvedic medicine usage, he was subjected to heavy metal screening, which revealed elevated blood lead level (BLL 83.6 $\mu \mathrm{g} / \mathrm{dL}$ ), with normal blood/urine levels of arsenic, mercury, cadmium and chromium. Skeletal survey did not reveal dense metaphyseal lines. He was managed with intravenous calcium disodium EDTA at $1 \mathrm{~g} / \mathrm{m}^{2}$ for 5 days, to which he responded with a reduction in BLL and clinical improvement.

In the index case, due to short exposure to ayurvedic medication, the patient lacked the classic features of basophilic stippling and ring sideroblasts, which are often the earliest manifestations of lead poisoning. ${ }^{1}$ The onset of symptoms is relatively fast for subacute lead poisoning but probably commensurate with the degree of lead ingested. Ideally, estimating the lead level in ayurvedic medications would have implicated a cause-effect relation; however, this could not be done due to lack of mass spectrometry. Chelation therapy quenches lead from different body sites and expels it through urine, as seen in our patient. Therapy should be initiated when BLL is $>80 \mu \mathrm{g} / \mathrm{dL}$ in asymptomatic and $>50 \mu \mathrm{g} / \mathrm{dL}$ in symptomatic adults.

Although over $95 \%$ of lead exposures are occupational, ayurvedic medicines are recognised as a source of lead poisoning and are responsible for $2 \%$ of non-occupational exposures. ${ }^{2}$ Ayurvedic

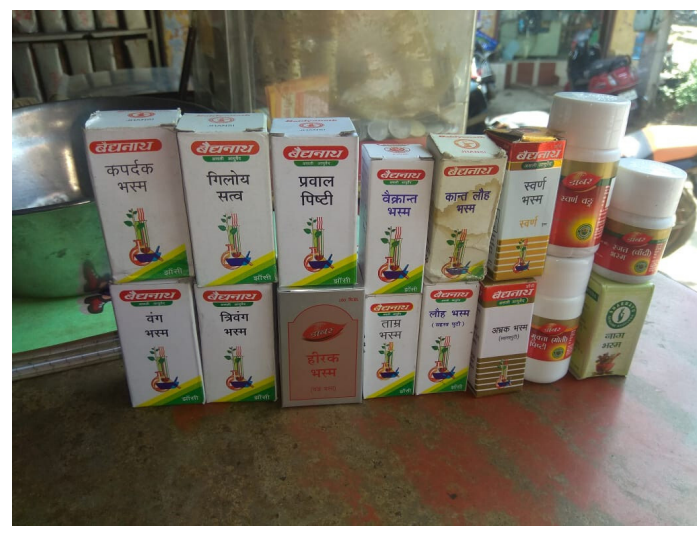

Figure 1 All the ayurvedic medications the patient was consuming to aid in bodybuilding.

medicines incorporate heavy metals (eg, mercury, lead and zinc) as ashes ('bhasmas'), a practice known as 'Rasa Shastra', and these are claimed to be safe and therapeutic if properly prepared and administered. ${ }^{3}$ A comprehensive analysis of 193 ayurvedic preparations revealed heavy metals in around 20\%, with lead and mercury 100-10 000 times greater than acceptable levels. ${ }^{4}$ Lead intoxication associated with ayurvedic medicines is increasingly reported due to lack of government regulations on the efficacy and safety and ready off-the-shelf availability as herbal remedies in food stores or through the internet. ${ }^{5}$

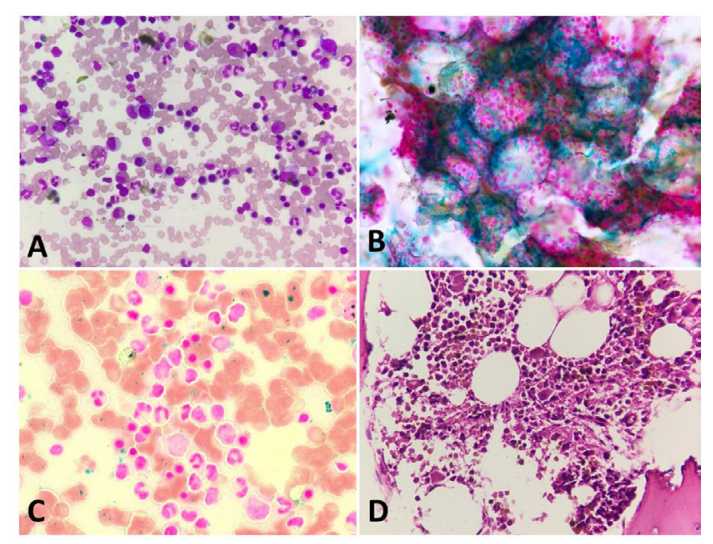

Figure 2 (A) Bone marrow aspirate with erythroid and myeloid precursors (May-Grunwald-Giemsa stain, 400x). (B) Bone marrow aspirate with increased iron stores, grade 4 (Perls' stain, 400x). (C) Bone marrow aspirate shows erythroid precursors, no ring sideroblasts (Perls' stain, 400x). (D) Bone marrow biopsy with dyspoietic hypolobated megakaryocytes (H\&E stain, 400x). 


\section{Patient's perspective}

I was unaware of the adverse effects of these medicines. In an enthusiasm to prepare well for the upcoming sports events and do better, I resorted to these drugs. I should have taken the consult of an expert in Ayurvedic medicines before using it. In the long run, my enthusiasm cost me heavily as I missed the opportunity to participate in the sports event.

\section{Learning points}

- Unprescribed consumption of ayurvedic medicines can lead to severe adverse effects.

- Individuals on ayurvedic medications who present to the hospital with atypical symptoms should be evaluated for heavy metal overdose.

- Self-medication based on internet advice to help in bodybuilding, as in our case, can cause severe organ toxicity.

The patient in this case has taken unsupervised ayurvedic medicines for bodybuilding, leading to lead poisoning. This case illustrates the impact of ayurvedic medicines, supplements and other non-prescription medicines on patients' health.
Acknowledgements We would like to thank Dr Kundan, Dr SK Singh, Dr Revanth, Dr Tathagata Chatterjee and Dr PK Sharma for support in managing this patient.

Contributors All authors were actively involved in the management of the patient. RB, UY and SKP were the treating physicians. VS was the reporting haematopathologist. All authors perused the manuscript before submission.

Funding The authors have not declared a specific grant for this research from any funding agency in the public, commercial or not-for-profit sectors.

Competing interests None declared.

Patient consent for publication Obtained.

Provenance and peer review Not commissioned; externally peer reviewed.

ORCID iD

Uday Yanamandra http://orcid.org/0000-0002-0546-6585

\section{REFERENCES}

1 Valentine WN, Paglia DE, Fink K, et al. Lead poisoning: association with hemolytic anemia, basophilic stippling, erythrocyte pyrimidine $5^{\prime}$-nucleotidase deficiency, and intraerythrocytic accumulation of pyrimidines. J Clin Invest 1976:58:926-32.

2 Centers for disease control and prevention adult blood lead epidemiology and surveillance-2008-2009. MMWR 2011;60:841-5.

3 Savrikar SS, Ravishankar B. Introduction to 'Rasashaastra' the latrochemistry of Ayurveda. Afr J Tradit Complement Altern Med 2011;8:66-82.

4 Saper RB, Phillips RS, Sehgal A, et al. Lead, mercury, and arsenic in US- and Indian-manufactured Ayurvedic medicines sold via the Internet. JAMA 2008:300:915-23.

5 Gunturu KS, Nagarajan P, McPhedran P, et al. Ayurvedic herbal medicine and lead poisoning.J Hematol Oncol 2011;4:51.

Copyright 2020 BMJ Publishing Group. All rights reserved. For permission to reuse any of this content visit

https://www.bmj.com/company/products-services/rights-and-licensing/permissions/

BMJ Case Report Fellows may re-use this article for personal use and teaching without any further permission.

Become a Fellow of BMJ Case Reports today and you can:

Submit as many cases as you like

Enjoy fast sympathetic peer review and rapid publication of accepted articles

- Access all the published articles

- Re-use any of the published material for personal use and teaching without further permission

Customer Service

If you have any further queries about your subscription, please contact our customer services team on +44 (0) 2071111105 or via email at support@bmj.com.

Visit casereports.bmj.com for more articles like this and to become a Fellow 